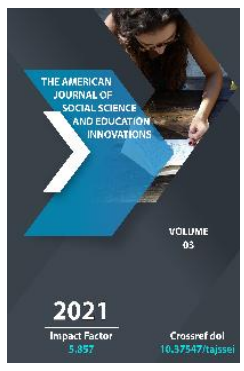

\title{
Initiative Capability: A Survey Of The Talent Of Society In The Australian Rail Corporarion
}

\author{
Jack Blackham
}

Department Of Social Science And Management, University Of Murdoch, Australia

\section{ABSTRACT}

This paper examines the significance of administration ability in the rail business in Australia. In the same way as other different nations all throughout the planet, rail is grieved by its capacity to pull in new ability as more seasoned pioneers with specific information resign. This investigation tried to recognize whether the area is taking advantage of the ability previously existing inside, realizing the obstructions looked in pulling in new corporarion contestants, and questions how can be dealt with fortify current ways to deal with creating pioneers. In investigating the importance of initiative ability, from an abilities based viewpoint with three degrees of pioneers, mixed strategies utilizing semiorganized meetings and a review were used. The investigation is significant on the grounds that it centers around individuals parts of the business, a little explored space of rail that has significant ramifications for how workers are locked in and held. The discoveries recognized a specific outlook, culture and approach about initiative ability in associations that ignored the heterogeneity of rail association populaces, blocking certain gatherings of individuals from turning out to be pioneers. The venture distinguished that authority and other delicate abilities needed in the rail business are both under explored, and frequently underestimated, for the effect that they can have on execution and profitability of organizations. There are key messages from this examination for the two associations just as rousing rail corporarion pioneers .

\section{KEYWORDS}

Administration; ability; rail; Australia; grown-up learning; labor force advancement 
Australian rail corporarion pioneers have a place with an uncommon gathering. For quite a long time, they have cultivated the social develops of the business that are based on the establishments of custom and time. At the point when the business is changing drastically, this contextual analysis addresses labor force issues of who can be a pioneer later on, variety over heterogeneity, and the need to have another attitude about initiative ability in the Australian rail industry. Maturing pioneers with relevant information are resigning, and new working environment setups require various abilities for what's to come. Probably the best test to confront associations is one of enabling more youthful ages to see the pertinence of the business for a rail vocation. As of late, various rail affiliations have focused on authority issues due to the future effects on the whole labor force however little has changed. However, in different regions society like architects, merchants and operational staff have been pulled in to these ventures in manners that rail doesn't. In this situation, something can be gathered from what society are searching for in their chiefs, what associations might have the option to offer, and what abilities are required for pioneers in contemporary rail associations. Specifically, this paper diagrams the story of the Australian rail corporarion that is portrayed transcendently by male workers with solid, recorded practices and numerous family connects to rail. Restricted expansion of the rail labor force show ladies involving under of the all out rail professions, prevalently in client care, deals and administrative jobs . Senior experienced rail pioneers and administrators hold most of positions of authority while there is a huge initiative hole in the more youthful age bunches . Intensifying outer occasions, for example, the suffering choppiness in worldwide monetary business sectors and increasing expenses of living have additionally affected a few chiefs choices to keep up their positions and delay their retirement. Authority discernments and the high number of more seasoned laborers in rail essentially affect the inspiration and excitement of more youthful representatives seeking to an administration vocation in rail. Time to hold on to prevail in new jobs is one of the key reasons refered to by workers leaving the business on the grounds that noticeable profession pathways are smothered. Rail has a picture issue, regularly saw as an antiquated corporation by more youthful empployees. In the light of these topics, projected rail labor force challenges will be additionally affected if initiative capacity and the new monetary standards needed for supported business accomplishment in an information based economy are missing. Technique Leadership is worried about individuals, with the writing affirming that administration is a socially arranged capacity. Not at all like a large part of the other exploration directed in the rail business climate that examines hard realities about, for instance, designing, machines and numbers, a methodology that considered the diverse angles and intricacy of individuals required a methodology that was not simply high contrast. While quantitative examination is worried about a positivist way of thinking, subjective exploration is best material to social wonders where there are numerous inquiries to be addressed. Inquiries regarding meaning (how individuals sort out the world); questions that shed light on the specific circumstance; and questions that explore measures can 
uncover complex work environment governmental issues that may not approach in quantitative methodologies. While numbers can uncover the amount of individuals who accepted certain issues this methodology can't uncover why it occurred. In proceeding with this conversation about subjective examination, an interpretive methodology that has a way of thinking that looks to comprehend the wonder administration ability from the person's viewpoint and encounters is proposed. Hence, the examination may uncover variants of reality that might be comparative or not at all like those of others, and with various cases to information. Since the rail business has advanced quickly since liberation in 1993, with numerous pioneers encountering different hierarchical setups and various pioneers in power all through their functioning lives, the interpretive methodology included members' very own basic assessment variants, of what they would call, reality .

\section{METHOD}

Initiative is worried about individuals, with the writing affirming that authority is a socially arranged capacity. Not at all like a significant part of the other exploration led in the rail business climate that researches hard realities about, for instance, designing, machines and numbers, a methodology that considered the diverse angles and intricacy of individuals required a methodology that was not absolutely "dark and white". While quantitative exploration is worried about a positivist way of thinking, subjective examination is ideal appropriate to social marvels where there are numerous inquiries to be addressed. Inquiries regarding which means (how individuals figure out the world); questions that shed light on the unique circumstance; and questions that examine measures can uncover complex work environment legislative issues that may not approach in quantitative methodologies . While numbers can uncover the amount of individuals who accepted certain issues this methodology can't uncover why it occurred, how it was done or how much. Not to be completely conflicting, Thompson likewise thinks about that even inside subjective examination draws near, there is space to join components of estimation, for example, in ascertaining the number of, for instance.

\section{DISCUSSION}

This paper set off to address three examination questions: what is your job as an innovator in this association. Foundation For in any event twenty years in Australia, rail associations have been ceaselessly rebuilding. Numerous pioneers communicated the progressions as far as what they noticed and experience presently when contrasted with their encounters as more youthful representatives. Some mourned the changing essence of the rail business and the destruction of government possession with one pioneer depicting the way of life and history of rail as, ... a glad history... my family have more than 60 years in the Australian rail industry, more often than not as pioneers.

\section{CONCLUSION}

This examination intended to investigate how pioneers at chief, center and bleeding edge levels in the Australian rail corporarion comprehend authority ability, fully intent on developing our comprehension of the "gifts" 
needed for corporarion pioneers into what's to come. The exploration questions were tended to by looking at the abilities appreciated in different pioneers, through self-assessment of pioneer's present jobs and by proposing about the gifts that ought to be considered as significant for "great" pioneers in rail associations. Because of this investigation, four principle discoveries add to our comprehension of administration ability in the Australian rail industry. First and foremost, Australian rail corporarion authoritative designs are commonly founded on progressive models where there are characterized levels of administration at each level. Our examination tried to comprehend the abilities needed for pioneers at each level in light of the fact that the advantage of such designs are that workers can build up their authority vocation in an corporarion and association where there are very much expressed pathways. The examination tracked down that worldwide impacts and continuous change have reduced these pathways extensively and influenced the capacity of representatives to move between the various levels. At the chief level, representatives have been more portable and ready to expand on their expert capabilities and encounters to seek after various freedoms as pioneers. At the center and bleeding edge, numerous representatives have been dug in these lower level jobs since they are viewed as significant to keeping up rail procedure on an everyday premise when there is constant change. Through absence of chance or absence of interest, not accomplishing a proper capability and endeavoring to encounter various parts in the work environment, has kept many center and bleeding edge pioneers to long lasting initiative vocations at these levels. Furthermore, various abilities are needed at the distinctive administration levels which got clear through this examination. Characterizing the authority gifts needed at each level is perceived as a sound procedure that can give a guide to pathways to future administration vocations in rail. At the chief level, pioneers showed solid specialized mastery and formal capabilities and experience that added to their capacity to rise above to various jobs.

\section{REFERENCES}

1. Australasian Railway Association Inc. A Rail Revolution: Future Capability Identification and Skills Development for the Australasian Rail Industry.

2. Williamsons, Michelle clark, lingans.h, N.somash, and Rolyn Camron. Fascination and picture for the australian rail industry.

3. Mahendra Anuska, j.michel land, and a. varsi. Estimating Rail Workforce Needs.

4. Beken tn, Nick Bristol. cavan, I.john, m ashun, B. The matter of australia's rail routes: Proceedings from the australian railroads business and financial aspects meeting. In Proceedings of Australian Railways Business and Economics Conference.

5. P.iskin.d.chagndu The Changing Face of Rail: A Journey to the Employer of Choice.

6. P.araw, Ranu, and R.graval The part of instructive abilities in australian administration practice and efficiency. 